\title{
Texas Superstar and the Coordinated Educational and Marketing Assistance Program (CEMAP): How We Operate
}

Wayne A. Mackay, ${ }^{1}$ Steve W. George, ${ }^{1}$ Tim D. Davis, ${ }^{2}$ Michael A. Arnold,${ }^{3}$ R. Daniel Lineberger,${ }^{4}$ Jerry M. Parsons, ${ }^{5}$ Larry A. Stein, ${ }^{6}$ Greg G. Grant ${ }^{7}$

Additional INDEX wOrds. plant selection, plant evaluation

Summary. The Coordinated Educational and Marketing Assistance Program identifies outstanding landscape plants for Texas and provides support for the nursery industry, thereby making superior plants available to Texans. CEMAP funding comes directly from industry and from consumers through the sale of plant tags bearing the Texas Superstar logo ${ }^{\mathrm{TM}}$. Additionally, the Texas Nursery and Landscape Association and Texas Department of Agriculture is conducting a Texas Superstar ${ }^{\mathrm{TM}}$ publicity campaign. An estimated $\$ 10$ million in new plant sales have been generated during the first 10 years of this program. Because plants are chosen based on their performance under minimal input conditions, Texas SuperStars ${ }^{\mathrm{TM}}$ greatly reduce their impact on the urban environment.

The Coordinated Educational and Marketing Assistance Pro-
gram is a highly successful program conducted by horticultural
scientists and extension specialists of the Texas A\&M Agriculture Program and teaching faculty at Steven F. Austin State University. The key to this effort is found in the first word of the program's title, namely coordination and it is this attribute which makes the program successful. This coordination necessitates very close cooperation between extension, research and teaching personnel and members of the ornamentals industry. The CEMAP program is comprised of two boards. The CEMAP Executive Board is comprised solely of university personnel with eight individuals representing extension, research and teaching, plus two administrative liaisons. The CEMAP Industry Advisory Board has about 50 members from all segments of the ornamentals industry in Texas.

\footnotetext{
The cost of publishing this paper was defrayed in part by the payment of page charges. Under postal regulations, this paper therefore must be hereby marked advertisement solely to indicate this fact.

${ }^{1}$ Associate professor, Texas A\&M University, 17360 Coit Rd., Dallas, TX 75252-6599.

${ }^{2}$ Professor and resident director, Texas A\&M University, 17360 Coit Rd., Dallas, TX 75252-6599.

${ }^{3}$ Associate professor, Texas A\&M University, Dept. of Horticultural Sciences, College Station, TX 77843

${ }^{4}$ Professor, Texas A\&M University, Dept. of Horticultural Sciences, College Station, TX 77843.

${ }^{5}$ Professor, Texas Agricultural Extension Service, 3427 Northeast Parkway, San Antonio, TX 78218.

${ }^{6}$ Professor, Texas A\&M University Research and Extension Center, 1619 Garner Field Rd., Uvalde, TX 78802-1849.

${ }^{7}$ Lecturer, Stephen F. Austin State University, Box 13000, SFA Station, Nacogdoches, TX 75962-3000.
} 
The goals of the CEMAP program are 2-fold: 1) to ensure that consumers have access to and use the best, most environmentally responsible plant materials and products and 2 ) to help the green industry be as profitable as possible. A schematic summary of how CEMAP functions is shown in Fig. 1.

\section{Organization and methodology}

The first step in this program is the identification of promising plants by university personnel and industry leaders, followed by multiyear testing of the candidate plants at many locations (currently 25) throughout the state (Fig. 2). These sites represent all of the diverse climatic areas [USDA Hardiness Zones 6 to 9 (USDA, 1990)] in Texas. In addition to the varied climatic zones, there are dramatic differences in rainfall, evaporation rates, maximum temperatures, and soils. For example, far west Texas receives less than 10 inches $(25.4$ $\mathrm{cm}$ ) of annual rainfall with over 100 inches $(254 \mathrm{~cm})$ of evaporation, whereas east Texas receives more than 55 inches $(140 \mathrm{~cm})$ of annual rainfall with only minimal evaporation (U.S. Department of Commerce, 2000). As can be expected, few plants can tolerate all of these varied growing conditions but those that consistently demonstrate superior performance in a majority of the test locations are designated Texas Superstars ${ }^{\mathrm{TM}}$.

In some cases, there are propagation or production problems which need to be resolved prior to the educational and marketing campaign for a given Texas Superstar ${ }^{\mathrm{rm}}$ and further research is undertaken to solve these problems so that plants will be available in sufficient quantities to meet the consumer demand generated by CEMAP. An example is 'Texas Gold' columbine ( $A q^{-}$ uilegia chrysantha binckleyana), a plant native to far west Texas, which exhibited such erratic seed germination that its production was limited. Additionally, the amount of seed available was limited since the plant occurred in only a few very remote locations. Efforts were undertaken by researchers and extension specialists at the Texas A\&M Research and Extension Center in Dallas to improve germination percentage and also to provide initial quantities of seed to the nursery industry. Research improved seed germination to about $90 \%$ using alternating day/night tem- peratures, allowing 'Texas Gold' columbine to be commercially produced and promoted in the CEMAP program (Davis et al., 1993). Another example is that offirebush (Hamelia patens) (Davis et al., 1991).

Once superior plants are identified and production problems overcome, growers are advised of the upcoming marketing campaign. The notification is given well in advance ( 3 to 4 years notice is given for woody plants) so growers can produce the plant in sufficient numbers to meet the demand. In some cases, the executive board helps to produce and distribute stock plants in advance of production schedules. Retailers are notified in the fall before the following year's promotion and informed of the participating growers. Retailers are also supplied with informational materials to advise the public on the best cultural techniques for the plant. In many cases, training seminars are also conducted to educate the retailers about plants that are new to the area.

The final step in the CEMAP program is the coordinated media cam- paign, which encompasses newspaper, magazine, radio and television outlets. The media packets contain information on special attributes of the plant, how to use it in the landscape, and any special cultural care it might require. An example of a plant with special cultural requirements is 'New Wonder' scaevola (Scaevola aemula) . Because of its outstanding performance in large containers and its need for well drained soils, we recommend that it be used as an accent plant in a container or in raised beds rather than being planted directly in the alkaline, clay soils found in much of central and western Texas which typically results in chlorosis.

A recent addition to the CEMAP program is the development of a trademarked Texas Superstaris symbol and the use of the symbol on plant tags and other promotional items. A portion of the sales of these items are returned to the CEMAP program with the goal of making the program self-supporting. Consumers are encouraged to look for the Texas Superstar ${ }^{\mathrm{TM}}$ tag to ensure that they are getting well adapted, thor-

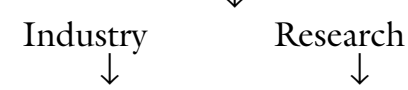

Identify promising concept

(several years in advance)

$\downarrow$

Test thoroughly

( 1 year of preliminary testing and at least 2 years of statewide testing) $\downarrow$

Involve industry in evaluation

Select outstanding plants to fulfill concepts

(up to 3 to 4 years in advance)

$\downarrow$

Advise growers on production practices

(minimum of 1 year in advance)

Brief retailers of final promotopn date

(6 to 9 months in advance)

$\downarrow$

Present employee training seminars and prepare point-of-purchase publications

( 4 to 5 months in advance)

$\downarrow$

Conduct aggressive and coordinated media campaign

(week befoer and throughout campaign period)

Evaluate success

(case study sales data over 2 to 3 years)

Fig. 1. Flow chart illustrating the various components of a successful Coordinated Educational and Marketing Assistance Program (CEMAP) for the nursery industry. 

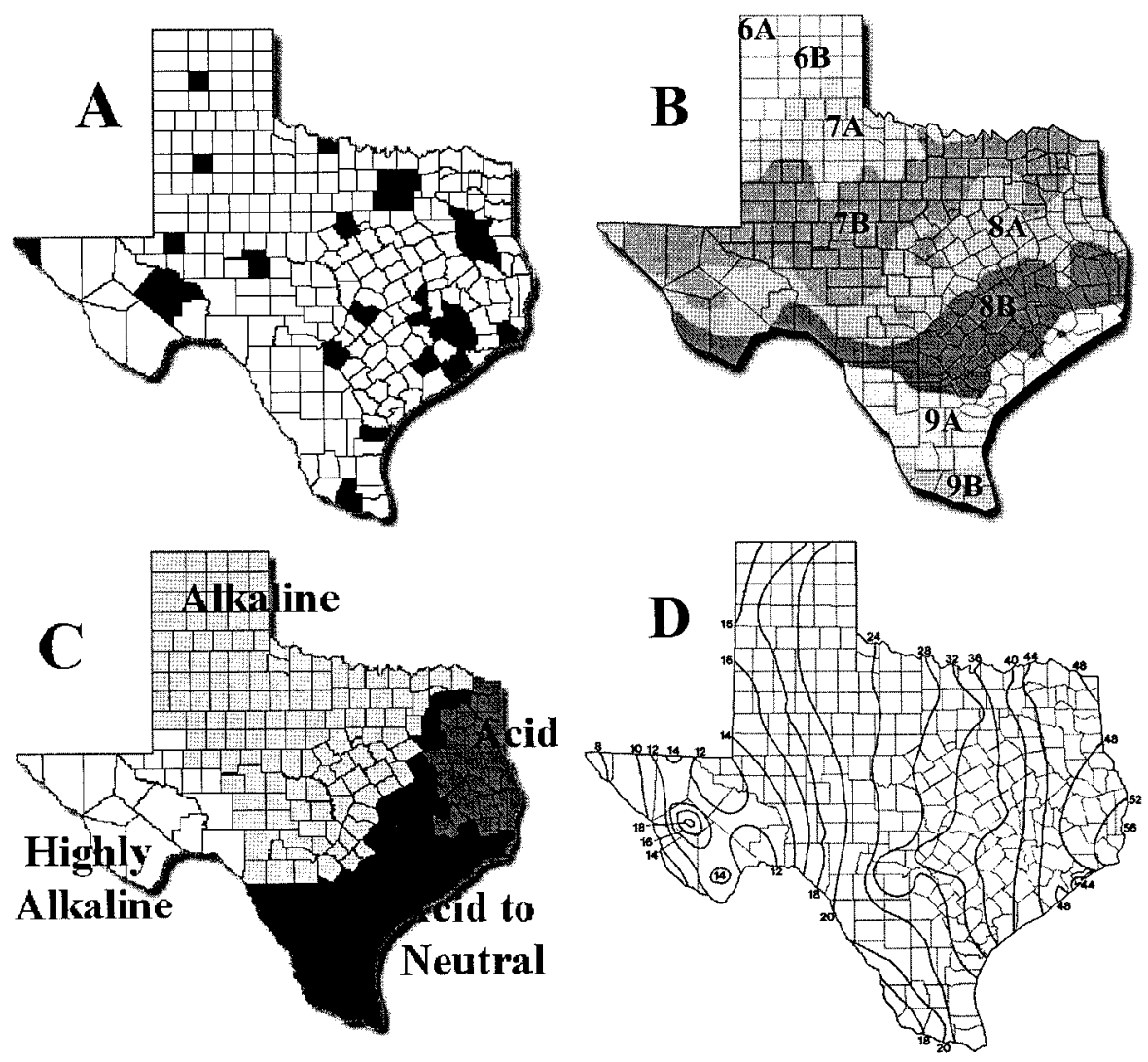

Fig. 2. (A) Coordinated Educational and Marketing Assistance Program (CEMAP) trial sites by county, indicated in black. (B) USDA Hardiness Zone Map of Texas (USDA, 1990). C. General soil pH map of Texas. D. Rainfall distribution in Texas, from $20.3 \mathrm{~cm}(8$ inches $) / y e a r$ in far west Texas to $142.2 \mathrm{~cm}$ (56 inches)/year in far east Texas. Isolines represent $10.2-\mathrm{cm}$ (4-inch) increments in yearly rainfall (Simpson, 1988).

oughly tested plant material. Growers are also encouraged to label all past CEMAP plant selections with the Texas Superstar ${ }^{\text {TM }}$ tags to help consumers identify other plants that give outstanding performance in Texas as well as maintain high sales levels of these plants.

A new avenue of information delivery is through the Internet. CEMAP program information is contained in the Aggie Horticulture web site (<http:// aggie-horticulture.tamu.edu/cemap/ >) supported by the Texas A\&M Department of Horticultural Science (Lineberger, 1994). The site contains detailed information and photographs for each Texas Superstar ${ }^{\text {TM }}$ plant. In addition to accessing plant information, growers can obtain information on both past and future promotions. To expand our information base on the Internet, a separate site is being developed to provide consumers with a wide range of information on the Texas Superstars ${ }^{\mathrm{TM}}$. To accomplish this, a new web address has been established, <http:// www.texassuperstar.com $>$ (Lineberger experience. This resulted in increased sales of $\$ 238,435$. Similarly, the 1999 'VIP' petunia (Petunia violacea) promotion case impact study at a multilocation retail nursery in Dallas and Fort Worth, Texas showed a 5000\% increase in number of plants sold and a $6000 \%$ increase in gross sales.

Not all plants promoted are annuals. Trees, shrubs and vegetables have also been promoted. Perhaps the most popular promotion has been for the 'Merced' tomato (Lycopersicon esculentum) promotion, which resulted in over 600,000 plants being sold the first weekend of the promotion indicating that consumers are looking for all types of plants thatare Texas SuperStars ${ }^{\text {tix }}$ (Arnold et al., 1998). In 1999, the CEMAP group estimated that approximately $\$ 10$ million in new plant sales have been generated as a result of the first 10 years of the CEMAP program. In addition to the business impact, there is an environmental impact resulting from the sales of the Texas Superstar ${ }^{\text {rs }}$ plants. Because plants are chosen based on their performance under minimal input conditions, Texas SuperStars ${ }^{\mathrm{Tx}}$ have minimal inputs of water and pesticides, greatly reducing their impact on the environment.

\section{Literature cited}

Arnold, M.A., W.A. Mackay, S. W. George and J. M. Parsons. 1998. CEMAP: A case study in statewide plant trials and promotion. Landscape Plant News 9 (4):7-10.

et al., 2000). The two sites will serve all of the informational needs of both the industry personnel and consumers.

\section{Impact and significance}

To date, 19 plants have been promoted statewide. Most of the promotions have been highly successful with some selling out in a few hours. An early promotion was with mari-mums, an african marigold (Tagetes erecta 'Antigua'), sold in late July through the beginning of September. Data was collected from a wholesale grower, a multilocation retail nursery with extensive advertising, a multilocation retail nursery with limited advertising, and a single retail nursery with extensive advertising. In 1989, the year prior to the CEMAP educational effort, a total of 1,000 plants were sold. In 1990 the first year of the CEMAP marimum educational effort, a total of 90,374 plants were sold and the following year 96,460 plants were sold without CEMAP educational efforts indicating that consumers returned to the stores based on their
Davis, T.D., S.W. George, A. Upadhyaya and J. Parsons. 1991. Propagation of firebush (Hamelia patens) by stem cuttings. J. Environ. Hort. 9:57-61.

Davis, T.D., D. Sankhla, N. Sankhla, and A. Upadhyaya. 1993. Improving seed germination of Aquilegia chrysantha by temperature manipulation. HortScience 28:798-799.

Lineberger, R.D. 1994. Aggie horticulture. 10 Apr. 2001. <http://aggie-horticulture.tamu.edu>.

Lineberger, R.D., J. Parsons, and S.W. George. 2000. Texas Superstars. 10 Apr. 2001. <http:/

Simpson, B.J. 1988. A field guide to Texas trees. Texas Monthly Press, Austin.

U.S. Department of Commerce, NOAA, Southern Regional Climate Center. 2000. Comparative climate data for the United States. 10 Apr. 2000. <http:// www.srcc.lsu.edu/ccd.html>.

U.S. Department of Agriculture. 1990. USDA Hardiness Zone Map. Misc. Publ. 1475, U.S. Dept. Agr., Wash., D.C. /www.texassuperstar.com>. 